\title{
Oregano Essential Oil Improves Intestinal Morphology and Expression of Tight Junction Proteins Associated with Modulation of Selected Intestinal Bacteria and Immune Status in a Pig Model
}

\author{
Yi Zou, ${ }^{1,2}$ Quanhang Xiang, ${ }^{1,2}$ Jun Wang, ${ }^{1,2}$ Jian Peng, ${ }^{1,2}$ and Hongkui Wei ${ }^{1,2}$ \\ ${ }^{1}$ Department of Animal Nutrition and Feed Science, College of Animal Science and Technology, Huazhong Agricultural University, \\ Wuhan 430070, China \\ ${ }^{2}$ The Cooperative Innovation Center for Sustainable Pig Production, Wuhan 430070, China
}

Correspondence should be addressed to Jian Peng; pengjian@mail.hzau.edu.cn and Hongkui Wei; weihongkui@mail.hzau.edu.cn

Received 1 March 2016; Revised 3 May 2016; Accepted 8 May 2016

Academic Editor: Kai Wang

Copyright (C) 2016 Yi Zou et al. This is an open access article distributed under the Creative Commons Attribution License, which permits unrestricted use, distribution, and reproduction in any medium, provided the original work is properly cited.

\begin{abstract}
Oregano essential oil (OEO) has long been used to improve the health of animals, particularly the health of intestine, which is generally attributed to its antimicrobial and anti-inflammatory effects. However, how OEO acts in the intestine of pig is still unclear. This study was aimed at elucidating how OEO promotes the intestinal barrier integrity in a pig model. Pigs were fed a control diet alone or one supplemented with $25 \mathrm{mg} / \mathrm{kg}$ of OEO for 4 weeks. The OEO-treated pigs showed decreased $(P<0.05)$ endotoxin level in serum and increased $(P<0.05)$ villus height and expression of occludin and zonula occludens-1 (ZO-1) in the jejunum. These results demonstrated that the integrity of intestinal barrier was improved by OEO treatment. The OEO-treated pigs had a lower $(P<0.05)$ population of Escherichia coli in the jejunum, ileum, and colon than the control. This is in accordance with the greater inactivation $(P<0.05)$ of inflammation, which was reflected by the mitogen-activated protein kinase (MAPK), protein kinase $\mathrm{B}$ (Akt), and nuclear factor $\kappa \mathrm{B}(\mathrm{NF}-\kappa \mathrm{B})$ signaling pathways and expression of inflammatory cytokines in the jejunum. Our results show that OEO promotes intestinal barrier integrity, probably through modulating intestinal bacteria and immune status in pigs.
\end{abstract}

\section{Introduction}

The ability of the intestinal epithelium to function as a barrier between the external environment and the closely regulated internal milieu is essential for human and pig health $[1,2]$. Increased intestinal permeability is a potential factor of gastrointestinal dysfunction and pathology, including Crohn's disease, multiple organ dysfunction, bacterial translocation, food allergies, and acute pancreatitis $[3,4]$. Currently, antibiotics are widely available and have a variety of proposed beneficial effects to promote intestinal health, but the application of these drugs is limited by their toxicity and side effects [5]. Therefore, it is urgent to find alternative treatments with fewer side effects.

Oregano (Origanum vulgare L.) is an aromatic plant widely distributed throughout the Mediterranean area and
Asia [6]. Oregano essential oil (OEO), a volatile oil, is concentrated from natural plant products which contain the volatile aroma compounds. These mixtures of volatile compounds exert different biological actions, such as antimicrobial, anti-inflammatory, and antioxidative activities [7]. There have been evidences showing the therapeutic effects of OEO supplementation on barrier defects in the gut of mammals, including mouse, rat, and broiler models [8-10]. However, there has been no report about the use of OEO supplementation to improve the intestinal barrier integrity of pigs.

Several studies have indicated that intestinal microbiota and immune status are important factors that influence the function of the intestinal barrier [11]. Alteration of the microbial composition results in increased immune stimulation, epithelial dysfunction, or enhanced mucosal 
permeability [12]. In the present study, we hypothesized that dietary OEO supplementation promotes intestinal barrier integrity by regulating intestinal bacteria and inflammation. We thus would use the pig model to test this hypothesis and study the morphology and permeability of the intestine, the composition of the intestinal microbiota, the activation of innate immunity, and the expression of proinflammatory cytokines after OEO supplementation.

\section{Materials and Methods}

All animal handling protocols were approved by the Huazhong Agricultural University Animal Care and Use Committee guidelines.

2.1. Animals, Diets, and Treatments. A total of 170 pigs (Large White $\times$ Landrace) with an initial body weight (BW) of $72 \mathrm{~kg}( \pm 4.0 \mathrm{~kg})$ were obtained from the same farm (Wuhan China Pork Co. Ltd., Wuhan, China). The pens were located in a building at a temperature maintained between 15 and $25^{\circ} \mathrm{C}$. For the experiment, the 170 pigs were split into two groups according to the diet (each group of 85 pigs was further split into 5 replicate pens each holding 17 pigs): (1) control treatment without supplementation and (2) supplementation of OEO $(25 \mathrm{mg} / \mathrm{kg}$ of feed for $28 \mathrm{~d}$, asfed basis). The composition of the control diet is shown in Table 1. The OEO was in the form of a powder called Phytogen (Meritech Bioengineering Co. Ltd., Guangzhou, China). The components of OEO are shown in Supplementary Table S1 (see Supplementary Material available online at http://dx.doi.org/10.1155/2016/5436738). Pigs were allowed feed and water ad libitum over a period of 4 weeks.

2.2. Sample Collection. On the day of slaughter, between 9:00 and 14:00, a total of 12 pigs ( $100 \mathrm{~kg}$ BW), with 6 pigs from each dietary treatment, were transported in an open truck to the slaughterhouse. Blood samples were collected after electrical stunning and then quickly separated into five tubes. A $10 \mathrm{~mL}$ sample was placed on ice immediately, which was subsequently centrifuged at $1300 \times \mathrm{g}$ at $4^{\circ} \mathrm{C}$ for $15 \mathrm{~min}$ to obtain serum. The serum samples were stored at $-80^{\circ} \mathrm{C}$ for subsequent analysis. The digesta samples were immediately removed from the jejunum, ileum, and colon of each pig and stored at $-80^{\circ} \mathrm{C}$ until further analysis. Samples of the jejunum itself were removed from the middle jejunum segment and then rinsed with ice-cold physiological saline. One section was snap-frozen in liquid nitrogen and then stored at $-80^{\circ} \mathrm{C}$ until further analysis. Other sections of jejunum $(3 \mathrm{~cm})$ were kept in $4 \%$ neutral buffered formalin for gut morphological analysis.

2.3. Gut Morphological Analysis. The digestive tract was removed from the jejunum and fixed in $10 \%$ phosphatebuffered formalin. The samples were sectioned at $5 \mathrm{~mm}$ thickness and stained with hematoxylin and eosin. Villus height, villus width, and villus crypt depth were measured on the stained sections using a light microscope fitted with an image analyzer (Image Pro Plus 6.0, Media Cybernetics,
TABLE 1: Composition and analysis of the basal diet.

\begin{tabular}{|c|c|}
\hline & Basal diet* \\
\hline \multicolumn{2}{|l|}{ Composition $(\mathrm{g} / \mathrm{kg})$} \\
\hline Wheat & 380.00 \\
\hline Corn, grains & 464.10 \\
\hline Soybean meal (46\%) & 89.00 \\
\hline Monocalcium phosphate & 14.00 \\
\hline Limestone & 7.00 \\
\hline Mycetes adsorbent & 1.50 \\
\hline Antimildew agent & 0.50 \\
\hline Salt & 3.50 \\
\hline Soybean oil & 20.00 \\
\hline Ethoxyquin & 0.25 \\
\hline Probiotics & 0.20 \\
\hline Y402 premix ${ }^{\dagger}$ & 20.00 \\
\hline \multicolumn{2}{|l|}{ Analysis ${ }^{*}$} \\
\hline Dry matter, DM (\%) & 86.80 \\
\hline Metabolism energy $(\mathrm{MJ} / \mathrm{kg})$ & 13.20 \\
\hline Crude protein, CP (\%) & 13.90 \\
\hline Crude fiber (\%) & 2.80 \\
\hline Ash (\%) & 3.60 \\
\hline Fat $(\%)$ & 4.30 \\
\hline Calcium (\%) & 0.60 \\
\hline Phosphorus (\%) & 0.60 \\
\hline
\end{tabular}

${ }^{*}$ Control group (C) was fed with the above basal diet, whereas the oregano essential oil (OEO) group consumed the basal diet supplemented with $25 \mathrm{mg} / \mathrm{kg}$ OEO.

${ }^{\dagger}$ Premix contained per kg 10.5 g Fe, 1.4 g Cu, 8.5 g Zn, 4 g Mn, 7.5 mg Se, 30 mg I, $350 \mathrm{kIU}$ of vitamin A, $40 \mathrm{kIU}$ of vitamin D3, $1.5 \mathrm{kIU}$ of vitamin E, $50 \mathrm{mg}$ of vitamin $\mathrm{K} 3,50 \mathrm{mg}$ of vitamin $\mathrm{B} 1,150 \mathrm{mg}$ of vitamin $\mathrm{B} 2,100 \mathrm{mg}$ of vitamin B6, $0.1 \mathrm{mg}$ of vitamin B12, $86.4 \mathrm{~g}$ lysine, $17.5 \mathrm{~g}$ methionine, $25 \mathrm{~g}$ threonine, $4 \mathrm{~g}$ phytase, and $15 \mathrm{~g}$ choline (kIU: 1000 international units).

${ }^{\ddagger}$ Metabolism energy was calculated from data provide by Feed Database in China (1999).

Bethesda, MD, USA). Twenty villi and crypts were measured for each segment.

2.4. Measurement of Serum Endotoxin Level. Serum endotoxin level was measured by a quantitative chromogenic end point tachypleus amebocyte lysate endotoxin detection kit following the manufacturer's instructions (Xiamen TAL Experimental Plant Co., Ltd., China). Briefly, serum samples were diluted to 1:10 with water/Tris- $\mathrm{HCl}$ buffer. After centrifugation at $1270 \times \mathrm{g}$ for $10 \mathrm{~min}$, the supernatant was removed and incubated with limulus amebocyte lysate at $37^{\circ} \mathrm{C}$ for $10 \mathrm{~min}$, followed by incubation with the provided chromogenic substance for $6 \mathrm{~min}$. The absorbance at $545 \mathrm{~nm}$ was measured after the addition of appropriate reagents.

\subsection{Extraction of Microbial DNA from the Gastrointestinal} Tract Digesta. Total DNA of jejunum, ileum, and colon digesta was extracted and purified from gastrointestinal tract digesta using a QIAamp DNA Stool Kit (Qiagen, Germany) according to the manufacturer's instructions. DNA concentration was determined by spectrophotometry (NanoDrop). 
TABLE 2: Species and genus specific primers used for real-time PCR.

\begin{tabular}{|c|c|c|c|}
\hline Gene & Primers (sense/antisense $5^{\prime}-3^{\prime}$ ) & Size (bp) & Annealing temperature $\left({ }^{\circ} \mathrm{C}\right)$ \\
\hline Total bacteria & $\begin{array}{l}\text { F: ACTCCTACGGGAGGCAGCAG } \\
\text { R: ATTACCGCGGCTGCTGG }\end{array}$ & 175 & 60 \\
\hline Lactobacillus spp. & $\begin{array}{l}\text { F: CACCGCTACACATGGAG } \\
\text { R: TGGAAGATTCCCTACTGCT }\end{array}$ & 341 & 58 \\
\hline Escherichia coli & $\begin{array}{l}\text { F: CATGCCGCGTGTATGAAGAA } \\
\text { R: TTTGCTCATTGACGTTACCCG }\end{array}$ & 96 & 60 \\
\hline Enterococcus faecalis & $\begin{array}{l}\text { F: CCCTTATTGTTAGTTGCCATCATT } \\
\text { R: ACAATGGGAAGTACAACGAGT }\end{array}$ & 144 & 61 \\
\hline$T N F-\alpha$ & $\begin{array}{l}\text { F: CACCACGCTCTTCTGCCTACTG } \\
\text { R: TTGAGACGATGATCTGAGTCCTTGG }\end{array}$ & 115 & 63 \\
\hline$M C P-1$ & $\begin{array}{l}\text { F: GTCCTTGCCCAGCCAGATG } \\
\text { R: CGATGGTCTTGAAGATCACTGCT }\end{array}$ & 148 & 60 \\
\hline$I L-1 \beta$ & $\begin{array}{l}\text { F: AAAGGGGACTTGAAGAGAG } \\
\text { R: CTGCTTGAGAGGTGCTGATGT }\end{array}$ & 286 & 58 \\
\hline$I L-6$ & $\begin{array}{l}\text { F: AAGGTGATGCCACCTCAGAC } \\
\text { R: TCTGCCAGTACCTCCTTGCT }\end{array}$ & 151 & 60 \\
\hline$I N F-\gamma$ & $\begin{array}{l}\text { F: GAGCCAAATTGTCTCCTTCTAC } \\
\text { R: CGAAGTCATTCAGTTTCCCAG }\end{array}$ & 140 & 61 \\
\hline $\mathrm{ZO}-1$ & $\begin{array}{l}\text { F: GGCGCACGGCGAAGGTAATT } \\
\text { R: CTATCAAACTCAGGAGGCGGCACT }\end{array}$ & 405 & 60 \\
\hline Occludin & $\begin{array}{l}\text { F: GGAGTGATTCGGATTCTGTCTATGCT } \\
\text { R: CGCCTGGGCTGTTGGGTTGA }\end{array}$ & 423 & 60 \\
\hline$\beta$-actin & $\begin{array}{l}\text { F: CCAGGTCATCACCATCGG } \\
\text { R: CCGTGTTGGCGTAGAGGT }\end{array}$ & 158 & 60 \\
\hline
\end{tabular}

2.6. Protein Immunoblot Analysis. Briefly, $100 \mathrm{mg}$ of frozen tissue of jejunum was homogenized in $1 \mathrm{~mL}$ RIPA lysis buffer (with $1 \mathrm{mM}$ PMSF and $10 \mu \mathrm{L} / \mathrm{mL}$ phosphatase inhibitors). For nuclear p65 measurement, the nuclear fractions were isolated using the Nuclear/Cytosol Fractionation Kit (BestBio, China). Next, they were centrifuged at $12000 \times \mathrm{g}$ at $4^{\circ} \mathrm{C}$ for $10 \mathrm{~min}$ and the supernatants were collected for assay. After the protein concentration was determined by a standard BCA protein assay, protein sample was loaded per lane and separated on SDS-PAGE. The target protein was then electrophoretically transferred to nitrocellulose membranes, which were blocked in TBST (5\% nonfat milk, $10 \mathrm{mM}$ Tris, $150 \mathrm{mM} \mathrm{NaCl}$, and $0.05 \%$ Tween-20) for $2 \mathrm{~h}$. Next, they were incubated with first antibodies, anti-Phospho-p38 MAPK (1:1000, Cell Signaling, USA), anti-Phospho-JNK (1:1000, Cell Signaling, USA), anti-Phospho-ERK1/2 (1:1000, Cell Signaling, USA), anti-Phospho-Akt (1:1000, Cell Signaling, USA), anti-p38 MAPK (1:1000, Affbiotech, USA), antiJNK (1:1000, Affbiotech, USA), anti-ERK1/2 (1:1000, Affbiotech, USA), anti-Akt (1:1000, Affbiotech, USA), anti-ZO-1 (1:1000, Affbiotech, USA), anti-occludin (1:1000, Affbiotech, USA), anti-NF- $\kappa$ B p65 (1:1000, Cell Signaling, USA), antiPCNA (1:5000, BD Transduction Laboratories, San Diego, CA), or anti-actin antibodies (1:1000, Cell Signaling, USA) at $4^{\circ} \mathrm{C}$ overnight. After three washes with Tris-buffered saline containing $0.1 \%$ Tween-20, blots were incubated with the HRP-conjugated secondary antibodies, anti-rabbit IgG $(1: 15,000$, Jackson ImmunoResearch, USA) or anti-mouse IgG (1:15,000, Jackson ImmunoResearch, USA), for $2 \mathrm{~h}$ and were washed again. Chemiluminescence detection was performed using the ECL reagent (Thermo Scientific, Rockford, IL, USA) according to the manufacturer's instructions. Specific bands were detected and were analyzed and quantified by Image J Software (NIH, Bethesda, MD, USA).

2.7. Quantitative PCR. Total RNA was extracted from samples of jejunum using Trizol Reagent (Invitrogen, USA) according to the manufacturer's instructions. The DNA obtained from the intestinal luminal content was used as the template to analyze intestinal bacteria. Primers (Table 2) used in this study were either synthesized according to our previous protocols or designed with Primer 5.0 according to pig gene sequences. Real-time PCR was performed according to our previous study [10]. The relative expression of genes in the treatment group was normalized based on the values of the control group.

2.8. Statistics. Statistical analysis was performed using Prism software (Prism 5.0, GraphPad Software, La Jolla, CA). Numbers $(n)$ used for statistics are noted in the figures. All data were analyzed by $t$-test procedures of SAS ( $\mathrm{v} 8.2$, SAS Inst., Inc., Cary, NC). All the values were presented as means \pm standard error of the mean (SEM), and those at $P<0.05$ were considered significant.

\section{Results}

3.1. Morphology of the Jejunum. Morphology is a good indicator of the status of the intestine [13]. As shown in Figure 1, although no significant differences were observed in 


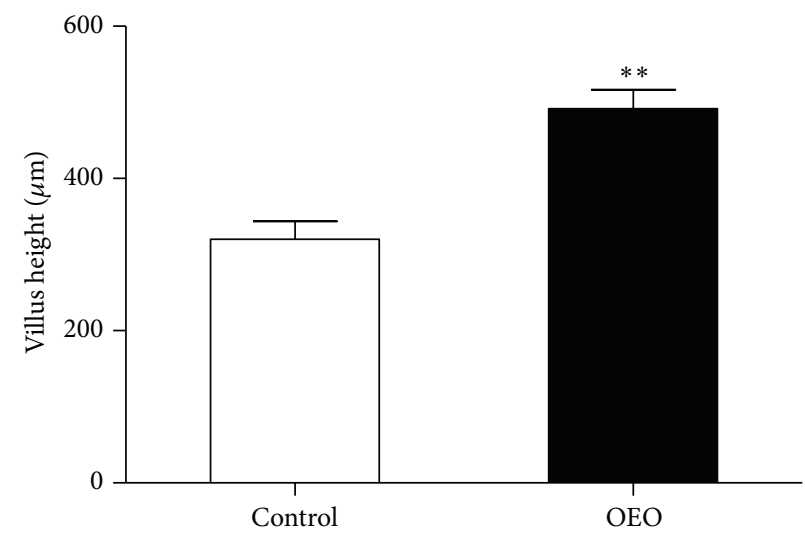

(a)

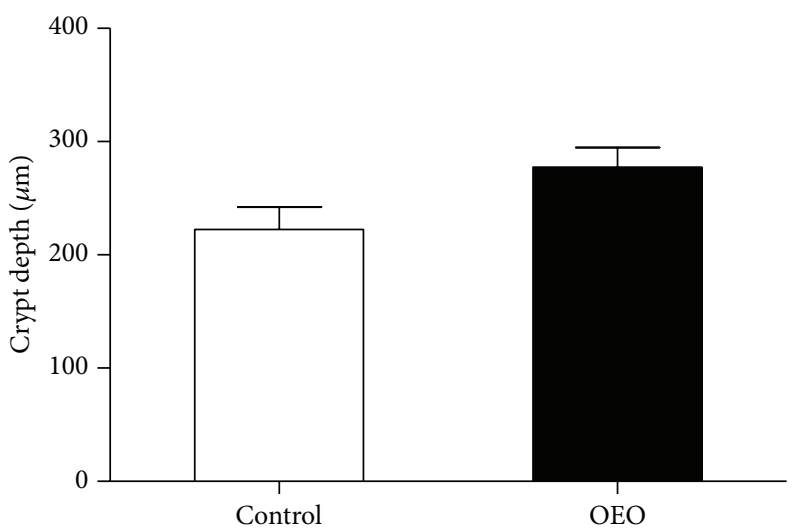

(c)

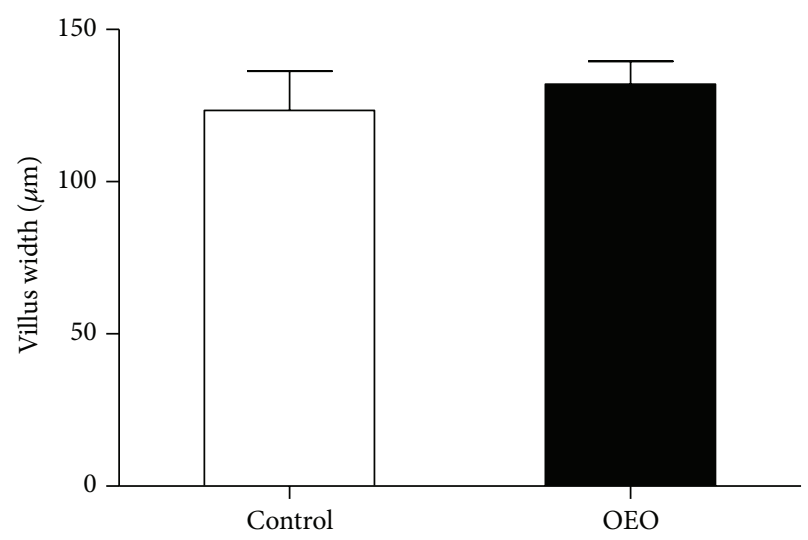

(b)

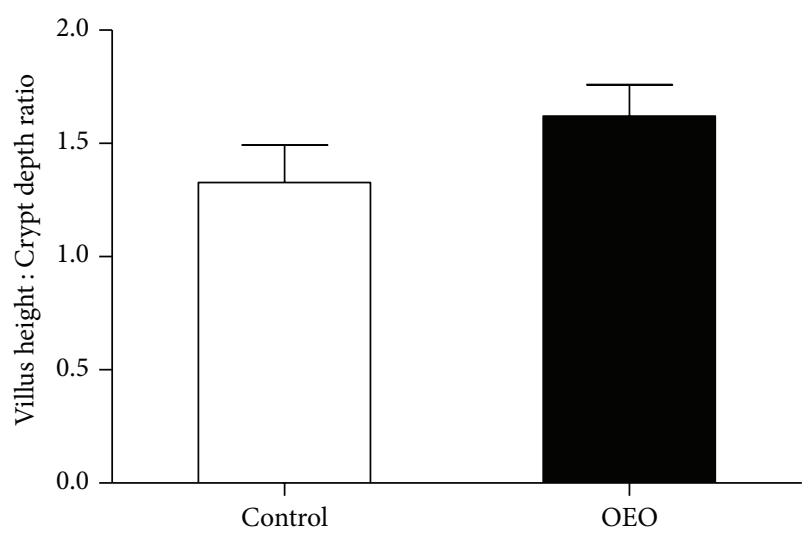

(d)

FIGURE 1: Effect of OEO on villus height, villus width, crypt depth, and the villus height: crypt depth ratio in the jejunum of pig. Values are means \pm SEM, $n=6 .{ }^{* *}$ Significantly different $(P<0.01)$ from the control group.

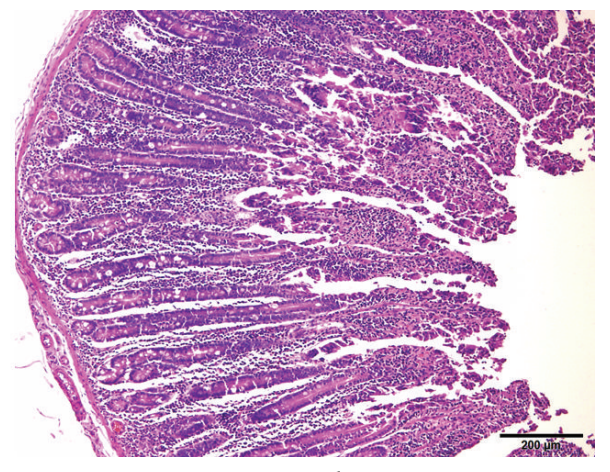

Control

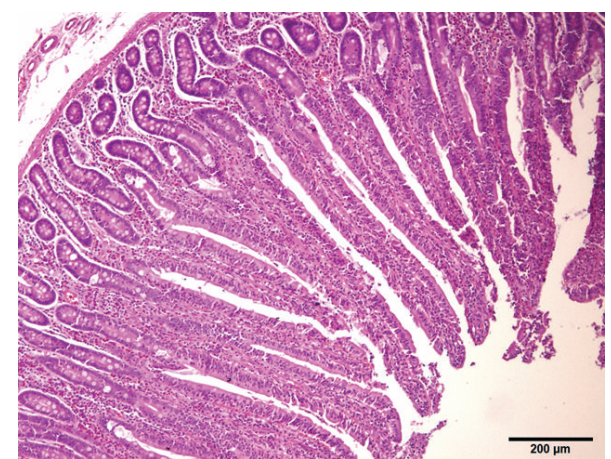

OEO

Figure 2: Effect of OEO on jejunum morphology in pig. The jejunum was cut off and fixed in 10\% formaldehyde-phosphate buffer and then stained with hematoxylin and eosin. Hematoxylin and eosin staining with original magnification $\times 100$. Bars represent $200 \mu \mathrm{m}$.

villus width, crypt depth, and the ratio of villus height to crypt depth between different treatments $(P>0.05)$, the villus height of the OEO-treated pigs was significantly higher than that of the control $(P<0.05)$. As shown in Figure 2 , the villi were scattered and seriously desquamated in the jejunum of the control group, while higher and intact villi were observed in the jejunum of OEO-treated pigs.
3.2. Endotoxin Levels in the Serum. Endotoxin level is a useful biomarker for evaluating the integrity of the gastrointestinal tract [14]. The effects of OEO supplementation on endotoxin level in the serum of pigs are shown in Figure 3. The OEO-treated pigs showed a significantly lower $(P<$ 0.05 ) concentration of endotoxin in the serum than the control. 


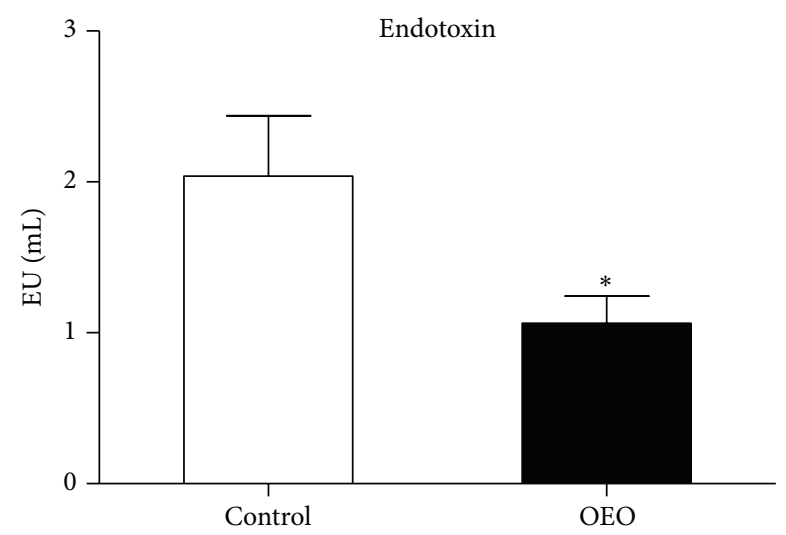

FIgURE 3: Effect of OEO on endotoxin levels in the serum of pig. Values are means \pm SEM, $n=6$. ${ }^{*}$ Significantly different $(P<0.05)$ from the control group.

\subsection{The Expression of Barrier Tight Junction Proteins in the} Jejunum. To determine the effects of OEO supplementation on the intestinal mucosal tight junction, the expression of occludin and zonula occludens-1 (ZO-1) was measured at mRNA and protein level. As shown in Figure 4, the mRNA levels of occludin and ZO-1 were significantly higher in the OEO-treated pigs than in the control group $(P<0.01)$. Similarly, OEO supplementation also increased $(P<0.05)$ the abundance of occludin and ZO-1 protein in the jejunum.

3.4. Major Microbiota in Different Regions of the Intestinal Tract. The effects of OEO supplementation on selected microbial populations in different intestinal tracts are shown in Figure 5. Although there were no significant differences $(P>0.05)$ in the total bacteria, Lactobacillus and Enterococcus spp. populations, the OEO-treated pigs had a significantly lower population of Escherichia coli (E. coli) in the jejunum $(P<0.05)$, ileum $(P<0.05)$, and colon $(P<0.01)$ compared with the control.

3.5. MAPKs, Akt, and NF- $\kappa B$ Pathways in the Jejunum. To investigate the mechanism responsible for the protective effect of OEO against inflammation in the jejunum of pigs, we further studied the underlying signaling pathways: the MAPKs, Akt, and NF- $\kappa \mathrm{B}$ pathways, which are induced by intestinal microorganisms and have been shown to be implicated in the induction of proinflammatory genes [15]. As shown in Figure 6(a), in the jejunum, OEO supplementation inhibited $(P<0.05)$ the activation of JNK, ERK1/2, and Akt due to lower abundance of phosphorylated JNK, ERK1/2, and Akt proteins compared with the control group. Similarly, OEO supplementation decreased $(P<0.05)$ the abundance of NF- $\kappa \mathrm{B}$ p 65 protein in the nucleus of the jejunum (Figure 6(b)). In contrast, OEO supplementation had no effect on phosphorylated p38.

3.6. The mRNA Levels of Proinflammatory Cytokines in the Jejunum. We examined the gene expression levels of four major inflammatory cytokines involved in mucosal inflammation in the jejunum tissues: interleukin-1 $\beta$ (IL$1 \beta$ ), interleukin-6 (IL-6), tumor necrosis factor- $\alpha$ (TNF- $\alpha$ ), monocyte chemotactic protein-1 (MCP-1), and interferon gamma $($ INF- $\gamma$ ). The results are presented in Figure 7 . The OEO-treated pigs showed significantly decreased $(P<0.05)$ levels of $T N F-\alpha, I L-1 \beta, I L-6, M C P-1$, and $I N F-\gamma$ compared with the control group.

\section{Discussion}

Defects in the intestinal barrier of animals can be induced by several types of ongoing environmental/life factors linked to physiology, psychology, antigens, and toxins [16]. Intestinal barrier defects are a serious problem in human as well as in pigs $[17,18]$. Various aromatic plants and their products have been reported to have beneficial effects for the intestine of animals [19]. Furthermore, in a previous study of our laboratory, it was also observed that the intestinal barrier could be improved by OEO supplementation in rat models [10]. However, to our knowledge, there has been no report about the effect of OEO on the intestinal barrier of finishing pigs. Therefore, in the present study, we investigated whether dietary supplementation of OEO could have a protective effect on the intestinal barrier and whether OEO could be used as a feed additive for pigs.

Intestinal mucosal permeability is directly related to the integrity of the intestinal barrier [20]. The function of the intestinal barrier can be commonly assessed by many indexes, such as serum endotoxin level, intestine morphology, and intestinal tight junction proteins [14, 21, 22]. In the present study, the height of villi in the jejunum of pigs was increased after treatment with OEO, indicating that OEO may protect the intestine against villous atrophy and epithelial cell necrosis. Consistently, the endotoxin level in pig serum decreased significantly after treatment with OEO. These results were in agreement with previous findings, which demonstrated that using an OEO supplemented diet improves the ileum villus height and decreases serum endotoxin level in broilers [23]. In addition, we found that the expression of occludin and $\mathrm{ZO}$ 1, the two major tight junction proteins in epithelia affecting the organization and the stability of the tight junction [21], was significantly decreased by OEO treatment. Similarly, Placha et al. [9] also observed that broilers fed with OEO had improved intestinal barrier integrity. Our results indicate that OEO supplementation can be a promising approach for protecting the intestinal barrier in pigs.

The intestinal microbiota plays critical roles in the maintenance of mucosal homeostasis [11]. A greater population of E. coli might affect the intestinal mucosa because they release toxins, resulting in an intimate interaction between the microbiota and the host enterocytes $[24,25]$. The abundance and composition of intestinal bacteria can be easily affected by various dietary factors [26]. In the present study, the dietary consumption of OEO decreased the populations of E. coli in the jejunum, ileum, and colon. These results are consistent with those of Tan et al. [27] and Sun et al. [23], who reported that that population of $E$. coli in intestinal is decreased in OEO-treated pigs and broilers, respectively. Thymol and carvacrol, the main active components of 


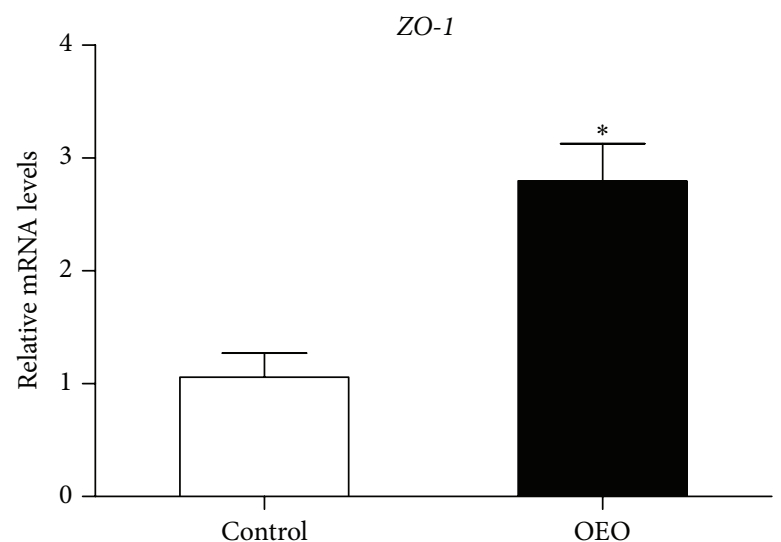

(a)
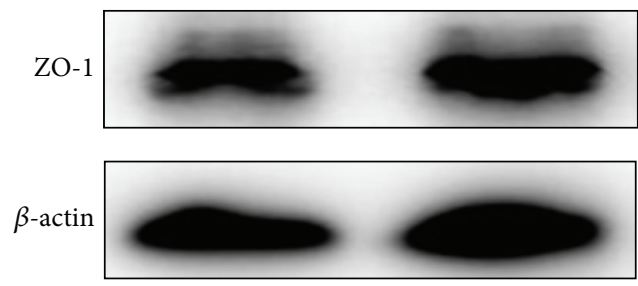

ZO-1

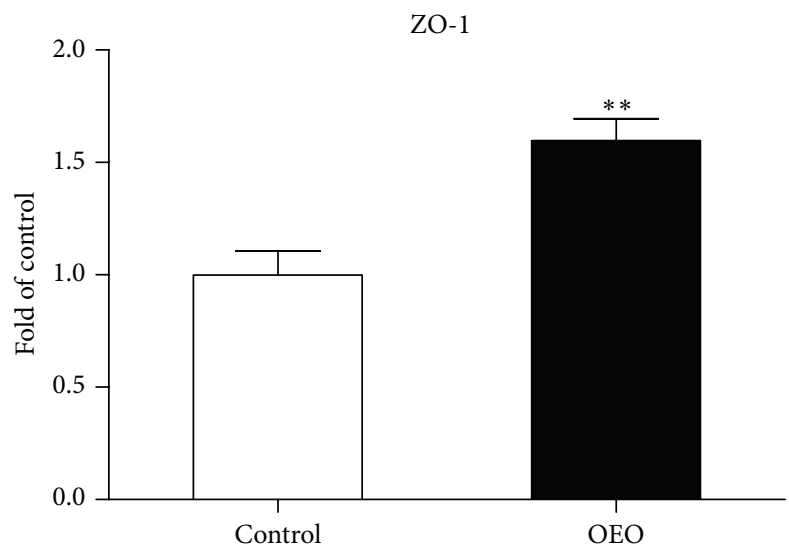

(c)

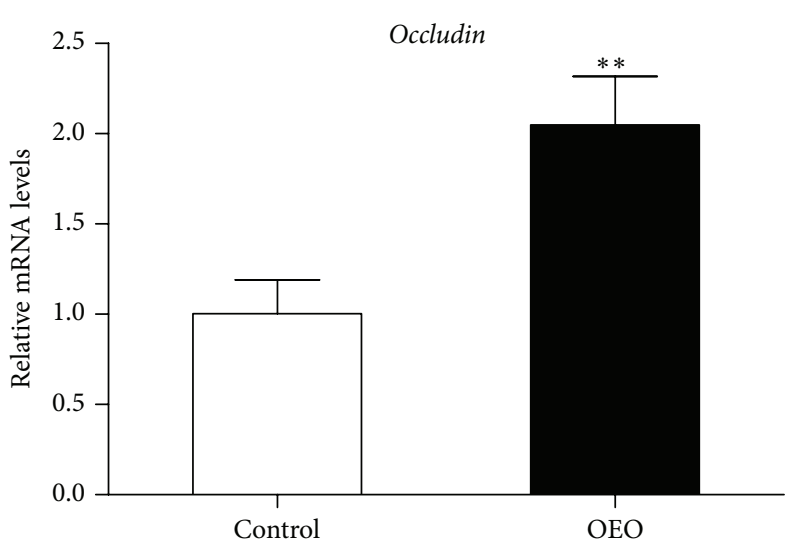

(b)
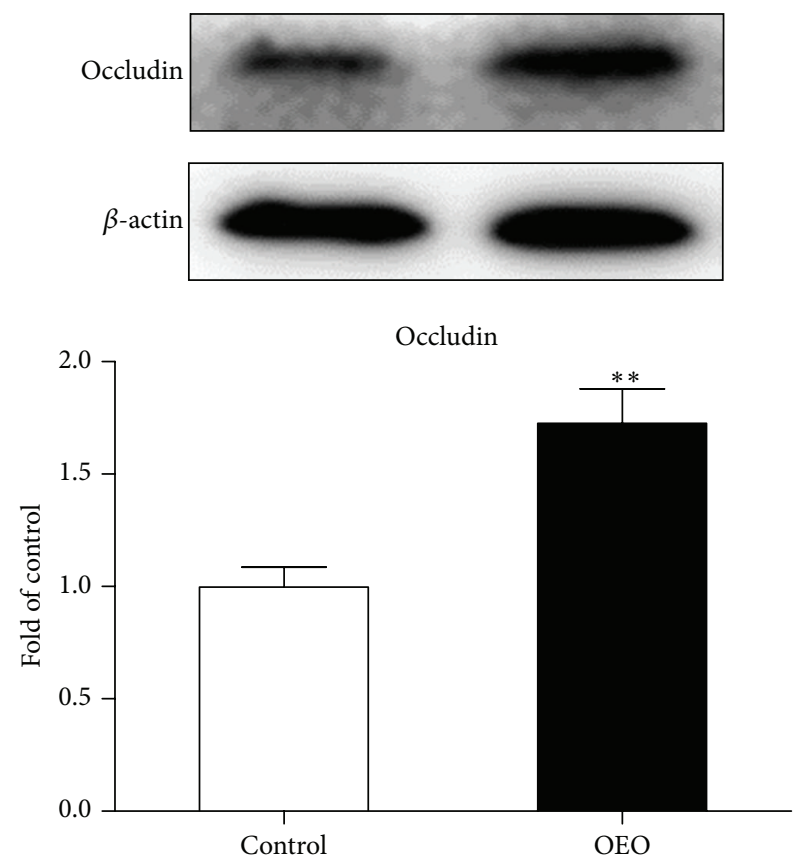

(d)

FIGURE 4: Effect of OEO on the ZO-1 and occludin levels in the jejunum of pig. (a) ZO-1 mRNA level, (b) occludin mRNA level, (c) ZO-1 protein level, and (d) occludin protein level. Expression of the selected genes was quantified by quantitative reverse transcription-PCR. Equal loading was assessed by $\beta$-actin immunoblotting. Values are means \pm SEM, $n=6$. * Significantly different $(P<0.05)$ from the control group. ** Significantly different $(P<0.01)$ from the control group. ZO-1, zonula occludens-1.

essential oil derived from thyme and oregano [7], were also documented to inhibit the proliferation of $E$. coli in vitro [28].

Recently, it has been recognized that the gut microbiota can influence the immune function beyond the gut [26]. The relationship between the immune system and the commensal flora is a precarious one, and perturbations in immune or epithelial homeostasis can lead to gut inflammation [29]. The initial sensing between bacteria and the host occurs through pattern recognition receptors [30]. In the intestine, the activated pattern recognition receptors trigger intestinal immune responses through various downstream signal transductions, such as MAPKs (e.g., p38 MAPK, ERK1/2, and JNK), Akt, and NF- $\kappa B[31,32]$. The Akt and MAPKs pathways modulate intestinal innate immunity through regulating the phosphorylation of inhibitory $\kappa \mathrm{B}$ kinases to activate the NF$\kappa \mathrm{B}$ pathway [33]. The NF- $\kappa \mathrm{B}$ pathway, which is activated by intestinal microbes, plays an important role in activating host proinflammatory responses [34]. The activation of these pathways is associated with the increased expression of TNF$\alpha$, IL-1 $\beta$, IL- 6, MCP- 1 , and INF- $\gamma[35,36]$. The innate immune system is activated as a defense mechanism and is generally beneficial [37]. However, if the inflammation is uncontrolled, the migration of innate immune cells such as neutrophils, macrophages, and dendritic cells into the target mucosal tissues will result in mucosal injury [32]. Regulating intestinal inflammation is of great significance for intestinal health $[15,38,39]$. OEO has been found to possess a significant antiinflammatory effect in vitro and in vivo $[8,40]$. The present 


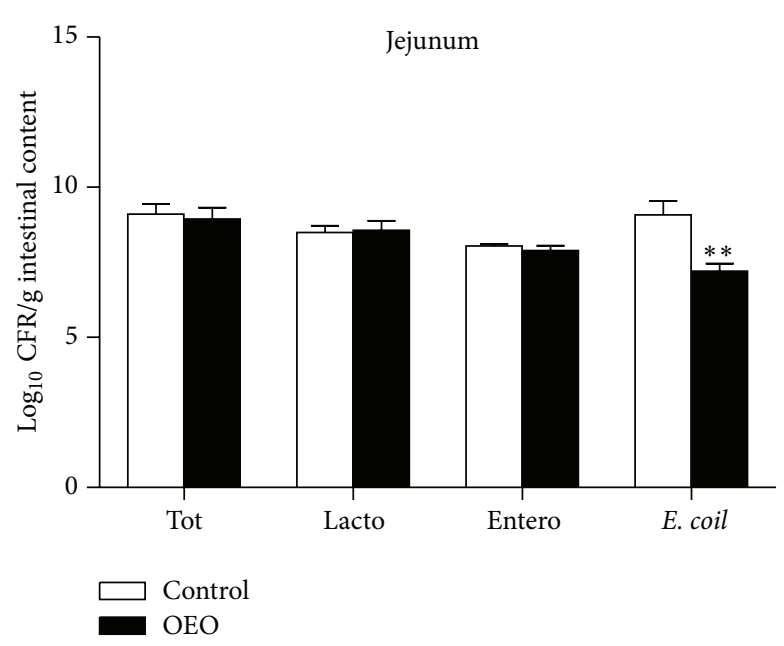

(a)

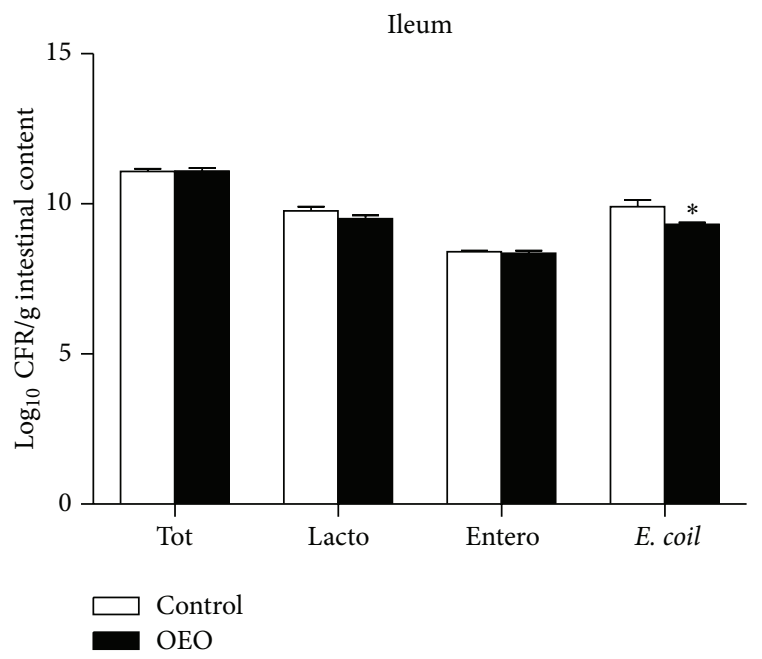

(b)

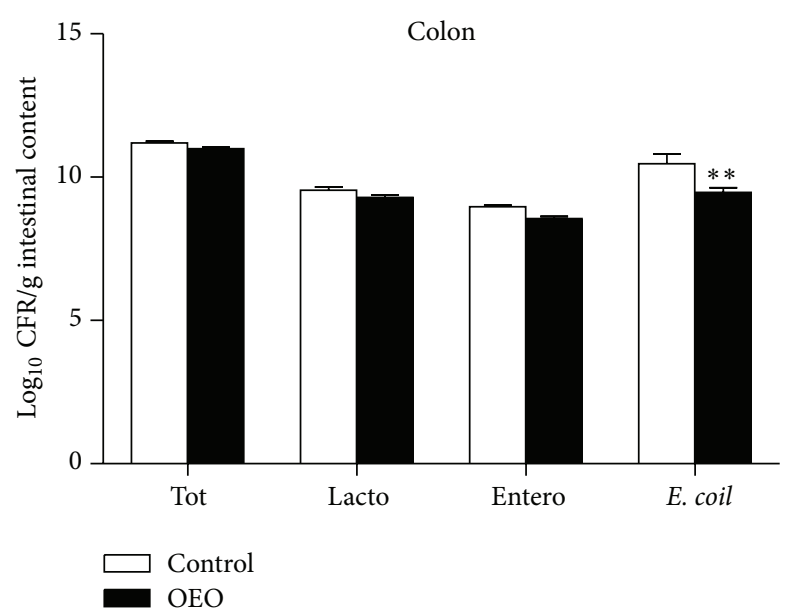

(c)

FIgURE 5: Effect of OEO on selected microbial populations in the jejunum, ileum, and colon tract of pig. Values are means \pm SEM, $n=6$. ${ }^{*}$ Significantly different $(P<0.05)$ from the control group. ${ }^{* *}$ Significantly different $(P<0.01)$ from the control group. Tot, total bacteria; Lacto, Lactobacillus spp.; Entero, Enterococcus faecalis; E. coli, Escherichia coli; $\log _{10}, 16 \mathrm{~S} \mathrm{rRNA}$ gene copies/g contents.

study indicates that OEO inhibits the inflammation in the intestine and downregulates the expression of $T N F-\alpha, I L-1 \beta$, $I L-6, I N F-\gamma$, and $M C P-1$ in the jejunum. Similarly, it has been previously shown that OEO effectively reduces the production of proinflammatory cytokine and thereby attenuates the TNBS-induced colitis in mice [41]. As the major component of OEO, carvacrol was also reported to probably influence the release and/or synthesis of inflammatory mediators [41]. As the mechanisms mediating the suppressive effects of OEO on inflammation are still unclear, we can only speculate that there might be several potential modes of action based on our results. One possibility could be the influence of OEO on NF- $\kappa$ B p 65 and phosphorylated MAPKs (ERK1/2 and JNK) and Akt pathways, which can activate the expression of the genes involved in immune and inflammatory responses, such as TNF- $\alpha, I L-1 \beta, I L-6, I N F-\gamma$, and $M C P-1$. On the other hand, intestinal microbial disorder (such as increased number of
E. coli) is a potent inducer of intestinal inflammation. The present study has shown that OEO can inhibit intestinal $E$. coli in pigs.

\section{Conclusion}

In conclusion, our results indicate that dietary administration of OEO can reduce the production of proinflammatory cytokines and promote the integrity of the intestinal barrier in pigs. The protective effect of OEO on the intestine is associated with the decrease of intestinal E. coli population and the inactivation of the JNK, ERK1/2, Akt, and NF$\kappa \mathrm{B}$ signaling pathways. These results will contribute to a better understanding of the possible mechanisms by which OEO promotes the integrity of the intestinal barrier in pigs. 

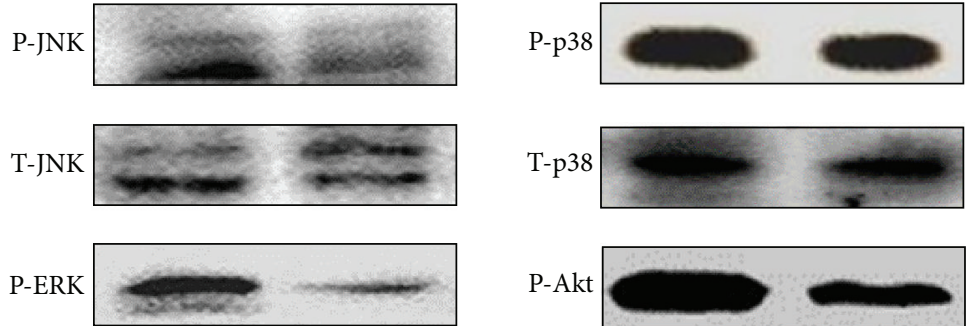

T-ERK

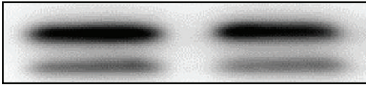

T-Akt

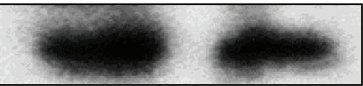

$\beta$-actin
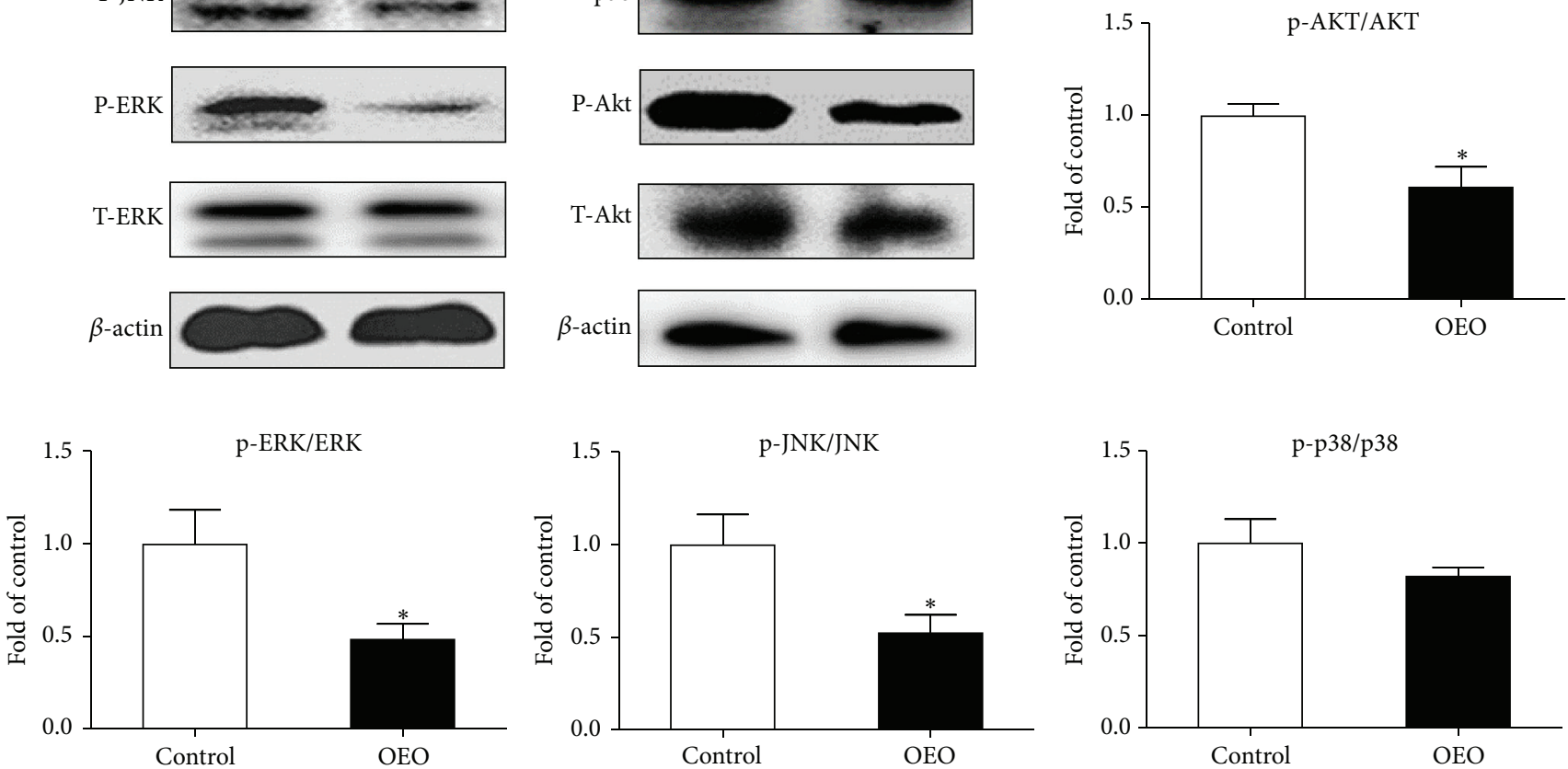

(a)

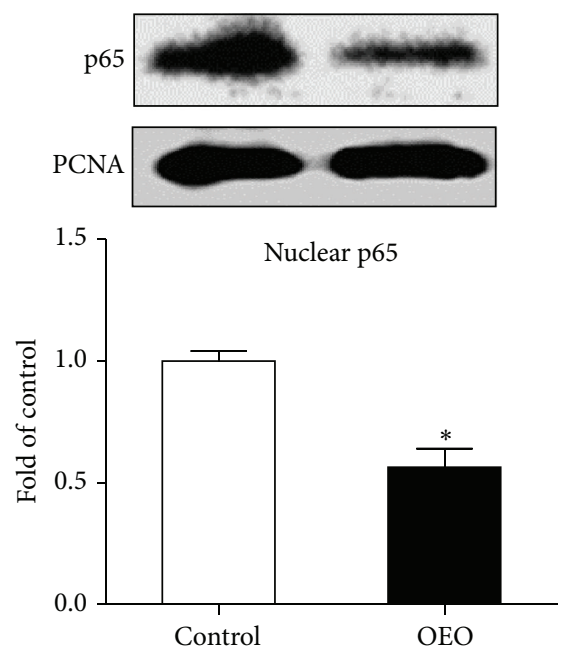

(b)

Figure 6: Effect of OEO on the levels of p-Akt, p-ERK, p-p38, p-JNK, and NF- $\kappa$ B p65 proteins in the jejunum of pig. (a) Akt protein, ERK protein, p38 protein, and JNK protein levels. Equal loading was assessed by $\beta$-actin immunoblotting. (b) Nuclear p65 protein level. Equal loading was assessed by PCNA immunoblotting. Values are means \pm SEM, $n=6$. ${ }^{*}$ Significantly different $(P<0.05)$ from the control group. ERK1/2, extracellular signal-regulated kinases $1 / 2$; JNK, c-Jun N-terminal protein kinase; Akt, protein kinase B; NF- $\kappa \mathrm{B}$, nuclear factor kappa B; P, phosphorylated; T, total.

\section{Competing Interests}

The authors declare that there is no conflict of interests regarding the publication of this paper.

\section{Acknowledgments}

This study was supported financially by the International S\&T Cooperation Projects of China (Grant no. 2013DFG32510) 


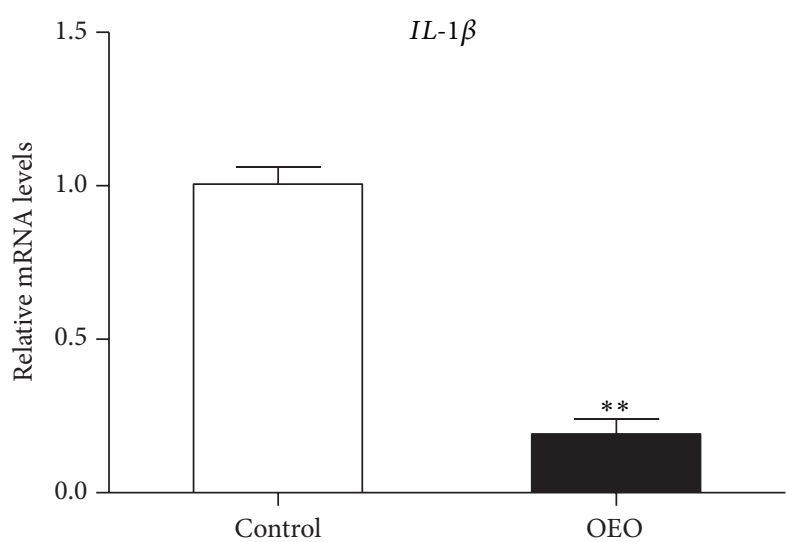

(a)

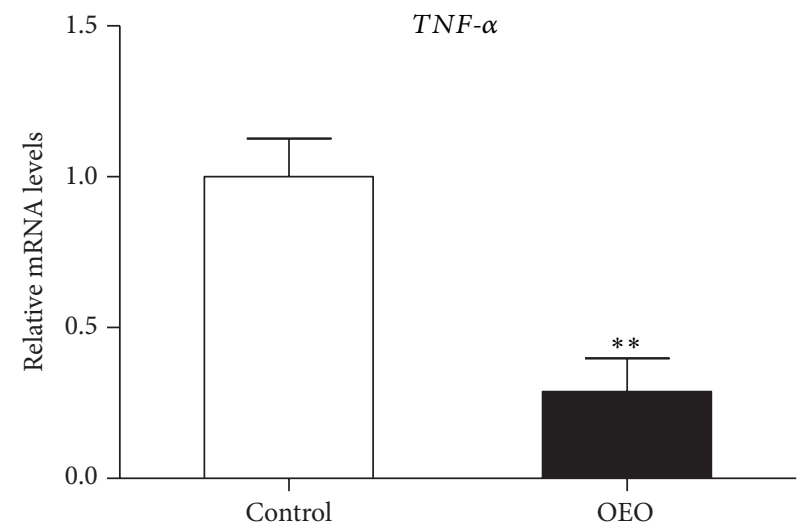

(c)

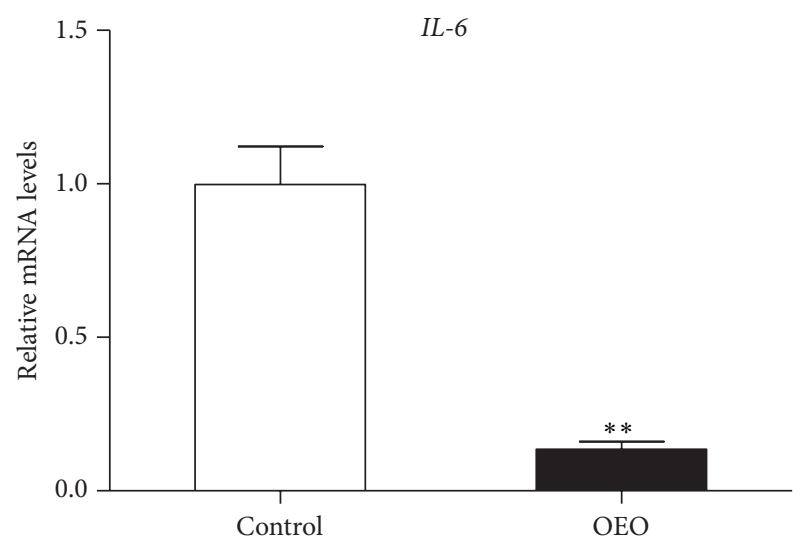

(b)

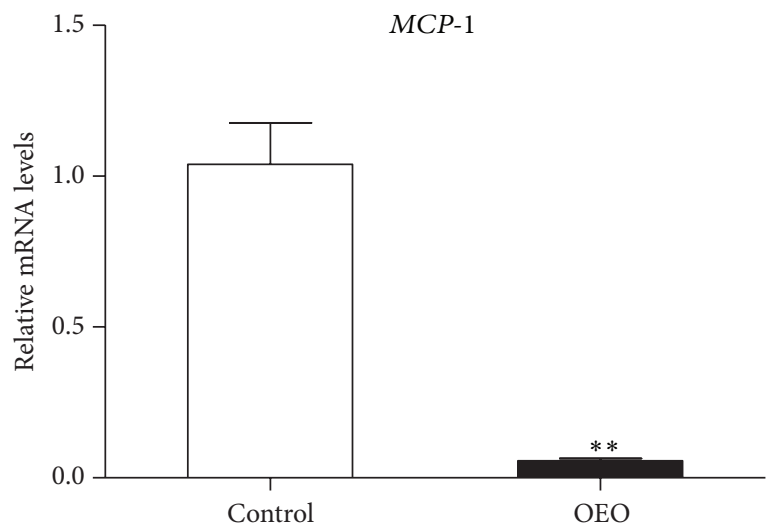

(d)

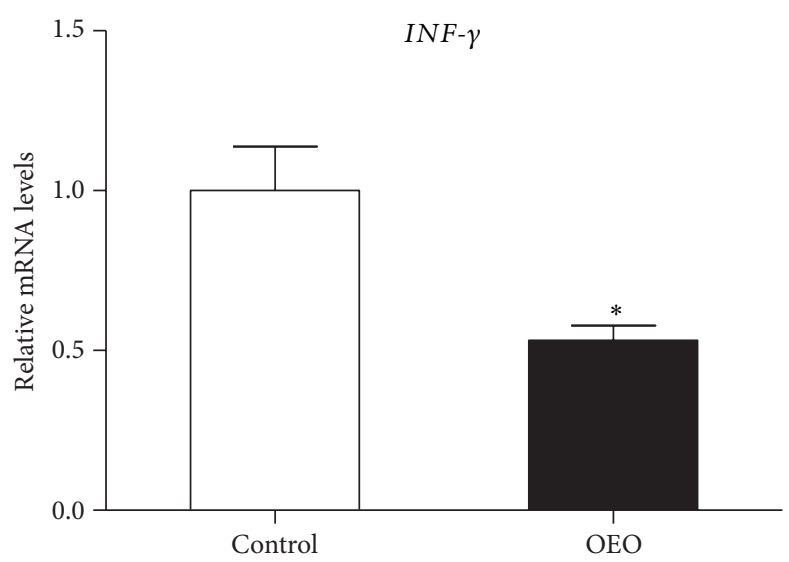

(e)

FIGURE 7: Effect of OEO on the mRNA levels of proinflammatory cytokines in the jejunum of pig. Expression of the selected genes was quantified by quantitative reverse transcription-PCR. (a) IL-1 $\beta$ mRNA level, (b) IL-6 mRNA level, (c) TNF- $\alpha$ mRNA level, (d) MCP-1 mRNA level, and (e) INF- $\gamma$ mRNA level. Values are means \pm SEM, $n=6$. ${ }^{*}$ Significantly different $(P<0.05)$ from the control group. ${ }^{* *}$ Significantly different $(P<0.01)$ from the control group. IL-1 $\beta$, interleukin-1 $\beta$; IL-6, interleukin-6; TNF- $\alpha$, tumor necrosis factor- $\alpha$; MCP-1, monocyte chemotactic protein-1; INF- $\gamma$, interferon gamma.

and the Key Technology Research and Development Program of Hubei Province (no. 2014ABB014). The authors are grateful to the colleagues for their helpful discussions and other kind members of the near laboratory for assisting with the sample collection.

\section{References}

[1] M. Camilleri, K. Madsen, R. Spiller, B. G. Van Meerveld, and G. N. Verne, "Intestinal barrier function in health and gastrointestinal disease," Neurogastroenterology \& Motility, vol. 24, no. 6, pp. 503-512, 2012. 
[2] I. P. Oswald, "Role of intestinal epithelial cells in the innate immune defence of the pig intestine," Veterinary Research, vol. 37, no. 3, pp. 359-368, 2006.

[3] H. T. Hassoun, B. C. Kone, D. W. Mercer, F. G. Moody, N. W. Weisbrodt, and F. A. Moore, "Post-injury multiple organ failure: the role of the gut," Shock, vol. 15, no. 1, pp. 1-10, 2001.

[4] O. D. Rotstein, "Pathogenesis of multiple organ dysfunction syndrome: gut origin, protection, and decontamination," Surgical Infections, vol. 1, no. 3, pp. 217-225, 2000.

[5] Y. H. Kho, M. O. Pool, F. G. A. Jansman, and J. W. Harting, "Pharmacotherapeutic options in inflammatory bowel disease: an update," Pharmacy World and Science, vol. 23, no. 1, pp. 17-21, 2001.

[6] M. Milos, J. Mastelic, and I. Jerkovic, "Chemical composition and antioxidant effect of glycosidically bound volatile compounds from oregano (Origanum vulgare L. ssp. hirtum)," Food Chemistry, vol. 71, no. 1, pp. 79-83, 2000.

[7] F. Bakkali, S. Averbeck, D. Averbeck, and M. Idaomar, "Biological effects of essential oils-a review," Food and Chemical Toxicology, vol. 46, no. 2, pp. 446-475, 2008.

[8] A. Bukovská, Š. Čikoš, Š. Juhás, G. Il’ková, P. Rehák, and J. Koppel, "Effects of a combination of thyme and oregano essential oils on TNBS-induced colitis in mice," Mediators of Inflammation, vol. 2007, Article ID 23296, 9 pages, 2007.

[9] I. Placha, J. Takacova, M. Ryzner et al., "Effect of thyme essential oil and selenium on intestine integrity and antioxidant status of broilers," British Poultry Science, vol. 55, no. 1, pp. 105-114, 2014.

[10] H.-K. Wei, G. Chen, R.-J. Wang, and J. Peng, "Oregano essential oil decreased susceptibility to oxidative stress-induced dysfunction of intestinal epithelial barrier in rats," Journal of Functional Foods, vol. 18, pp. 1191-1199, 2015.

[11] I. I. Ivanov and D. R. Littman, "Modulation of immune homeostasis by commensal bacteria," Current Opinion in Microbiology, vol. 14, no. 1, pp. 106-114, 2011.

[12] D. R. Littman and E. G. Pamer, "Role of the commensal microbiota in normal and pathogenic host immune responses," Cell Host \& Microbe, vol. 10, no. 4, pp. 311-323, 2011.

[13] A. Viveros, S. Chamorro, M. Pizarro, I. Arija, C. Centeno, and A. Brenes, "Effects of dietary polyphenol-rich grape products on intestinal microflora and gut morphology in broiler chicks," Poultry Science, vol. 90, no. 3, pp. 566-578, 2011.

[14] C. B. Forsyth, K. M. Shannon, J. H. Kordower et al., "Increased intestinal permeability correlates with sigmoid mucosa alphasynuclein staining and endotoxin exposure markers in early Parkinson's disease," PLoS ONE, vol. 6, no. 12, Article ID e28032, 2011.

[15] S. Qi, Y. Xin, Y. Guo et al., "Ampelopsin reduces endotoxic inflammation via repressing ROS-mediated activation of $\mathrm{PI} 3 \mathrm{~K} / \mathrm{Akt} / \mathrm{NF}-\kappa \mathrm{B}$ signaling pathways," International Immunopharmacology, vol. 12, no. 1, pp. 278-287, 2012.

[16] J. D. Söderholm and M. H. Perdue, "Stress and intestinal barrier function," American Journal of Physiology-Gastrointestinal and Liver Physiology, vol. 280, no. 1, pp. G7-G13, 2001.

[17] A. J. Moeser, L. B. Borst, B. L. Overman, and J. S. Pittman, "Defects in small intestinal epithelial barrier function and morphology associated with peri-weaning failure to thrive syndrome (PFTS) in swine," Research in Veterinary Science, vol. 93, no. 2, pp. 975-982, 2012.

[18] J. M. Mullin, N. Agostino, E. Rendon-Huerta, and J. J. Thornton, "Keynote review: epithelial and endothelial barriers in human disease," Drug Discovery Today, vol. 10, no. 6, pp. 395-408, 2005.
[19] I. Giannenas, E. Bonos, E. Christaki, and P. Florou-Paneri, "Essential oils and their applications in animal nutrition," Medicinal \& Aromatic Plants, vol. 2, no. 6, pp. 1-12, 2013.

[20] Y. Ma, S. Semba, M. R. I. Khan et al., "Focal adhesion kinase regulates intestinal epithelial barrier function via redistribution of tight junction," Biochimica et Biophysica Acta-Molecular Basis of Disease, vol. 1832, no. 1, pp. 151-159, 2013.

[21] T. Suzuki, "Regulation of intestinal epithelial permeability by tight junctions," Cellular and Molecular Life Sciences, vol. 70, no. 4, pp. 631-659, 2013.

[22] M. A. M. Vente-Spreeuwenberg, J. M. A. J. Verdonk, A. C. Beynen, and M. W. A. Verstegen, "Interrelationship between gut morphology and faeces consistency in newly weaned piglets," Animal Science, vol. 77, no. 1, pp. 85-94, 2003.

[23] Q. Sun, D. Liu, S. Guo, Y. Chen, and Y. Guo, "Effects of dietary essential oil and enzyme supplementation on growth performance and gut health of broilers challenged by Clostridium perfringens," Animal Feed Science and Technology, vol. 207, pp. 234-244, 2015.

[24] A. Finamore, M. Roselli, A. Imbinto, J. Seeboth, I. P. Oswald, and E. Mengheri, "Lactobacillus amylovorus inhibits the TLR4 inflammatory signaling triggered by enterotoxigenic Escherichia coli via modulation of the negative regulators and involvement of TLR 2 in intestinal Caco-2 cells and pig explants," PLoS ONE, vol. 9, no. 4, Article ID e94891, 2014.

[25] R. B. Sartor, "Microbial influences in inflammatory bowel diseases," Gastroenterology, vol. 134, no. 2, pp. 577-594, 2008.

[26] K. M. Maslowski and C. R. MacKay, "Diet, gut microbiota and immune responses," Nature Immunology, vol. 12, no. 1, pp. 5-9, 2011.

[27] C. Tan, H. Wei, H. Sun et al., "Effects of dietary supplementation of oregano essential oil to sows on oxidative stress status, lactation feed intake of sows, and piglet performance," BioMed Research International, vol. 2015, Article ID 525218, 9 pages, 2015.

[28] I. M. Helander, H.-L. Alakomi, K. Latva-Kala et al., "Characterization of the action of selected essential oil components on gram-negative bacteria," Journal of Agricultural and Food Chemistry, vol. 46, no. 9, pp. 3590-3595, 1998.

[29] T. T. MacDonald and G. Monteleone, "Immunity, inflammation, and allergy in the gut," Science, vol. 307, no. 5717, pp. 1920-1925, 2005.

[30] S. Akira, K. Takeda, and T. Kaisho, "Toll-like receptors: critical proteins linking innate and acquired immunity," Nature Immunology, vol. 2, no. 8, pp. 675-680, 2001.

[31] W. Ren, S. Chen, J. Yin et al., "Dietary arginine supplementation of mice alters the microbial population and activates intestinal innate immunity," The Journal of Nutrition, vol. 144, no. 6, pp. 988-995, 2014.

[32] R. J. Xavier and D. K. Podolsky, "Unravelling the pathogenesis of inflammatory bowel disease," Nature, vol. 448, no. 7152, pp. 427-434, 2007.

[33] N. D. Perkins, "Integrating cell-signalling pathways with NF- $\kappa \mathrm{B}$ and IKK function," Nature Reviews Molecular Cell Biology, vol. 8, no. 1, pp. 49-62, 2007.

[34] W.-K. Ren, J. Yin, X.-P. Zhu et al., "Glutamine on intestinal inflammation: a mechanistic perspective," European Journal of Inflammation, vol. 11, no. 2, pp. 315-326, 2013.

[35] M. F. Neurath, "Cytokines in inflammatory bowel disease," Nature Reviews Immunology, vol. 14, no. 5, pp. 329-342, 2014. 
[36] M. G. Vizoso Pinto, M. Rodriguez Gómez, S. Seifert, B. Watzl, W. H. Holzapfel, and C. M. A. P. Franz, "Lactobacilli stimulate the innate immune response and modulate the TLR expression of HT29 intestinal epithelial cells in vitro," International Journal of Food Microbiology, vol. 133, no. 1-2, pp. 86-93, 2009.

[37] M. Lamkanfi and V. M. Dixit, "Inflammasomes and their roles in health and disease," Annual Review of Cell and Developmental Biology, vol. 28, pp. 137-161, 2012.

[38] Y. J. Feng and Y. Y. Li, “The role of p38 mitogen-activated protein kinase in the pathogenesis of inflammatory bowel disease," Journal of Digestive Diseases, vol. 12, no. 5, pp. 327-332, 2011.

[39] M. Pasparakis, "Role of NF- $\kappa$ B in epithelial biology," Immunological Reviews, vol. 246, no. 1, pp. 346-358, 2012.

[40] A. Ocaña-Fuentes, E. Arranz-Gutiérrez, F. J. Señorans, and G. Reglero, "Supercritical fluid extraction of oregano (Origanum vulgare) essentials oils: anti-inflammatory properties based on cytokine response on THP-1 macrophages," Food and Chemical Toxicology, vol. 48, no. 6, pp. 1568-1575, 2010.

[41] F. V. Silva, A. G. Guimarães, E. R. S. Silva et al., "Antiinflammatory and anti-ulcer activities of carvacrol, a monoterpene present in the essential oil of oregano," Journal of Medicinal Food, vol. 15, no. 11, pp. 984-991, 2012. 


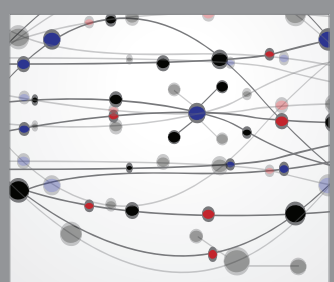

The Scientific World Journal
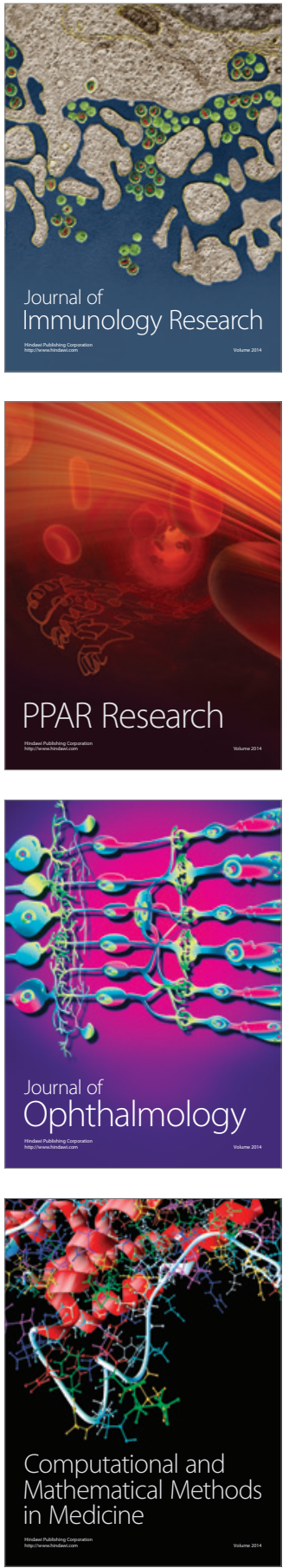

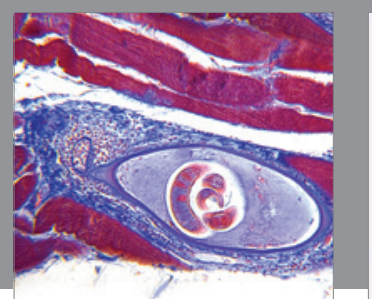

Gastroenterology Research and Practice

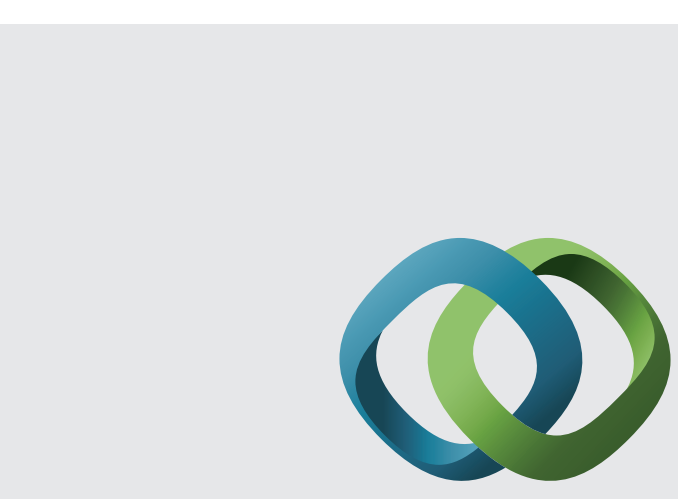

\section{Hindawi}

Submit your manuscripts at

http://www.hindawi.com
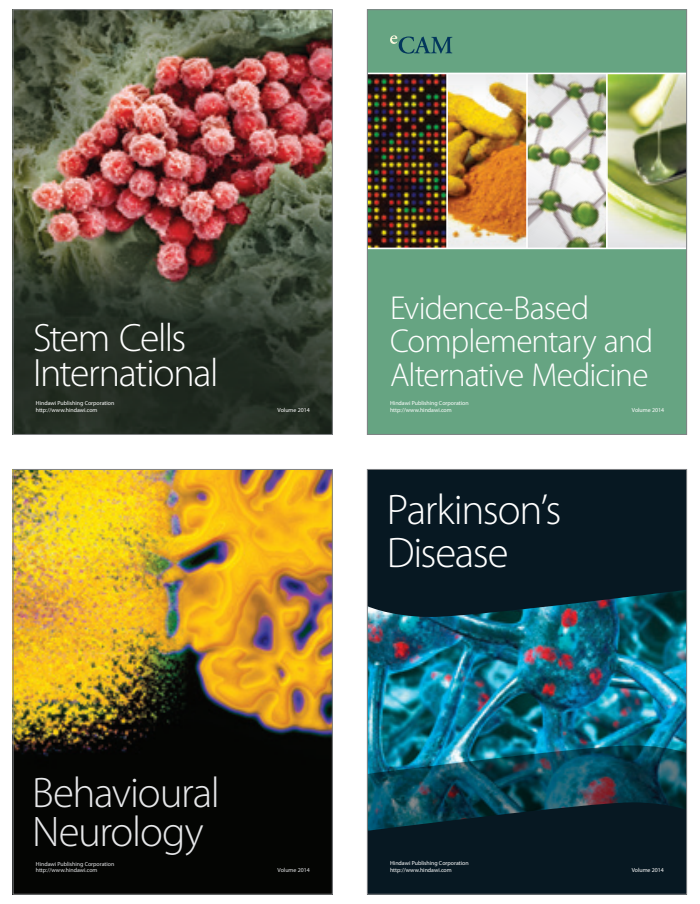
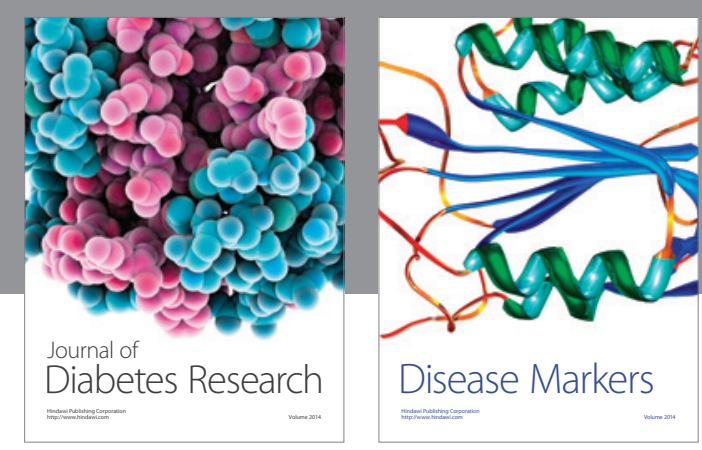

Disease Markers
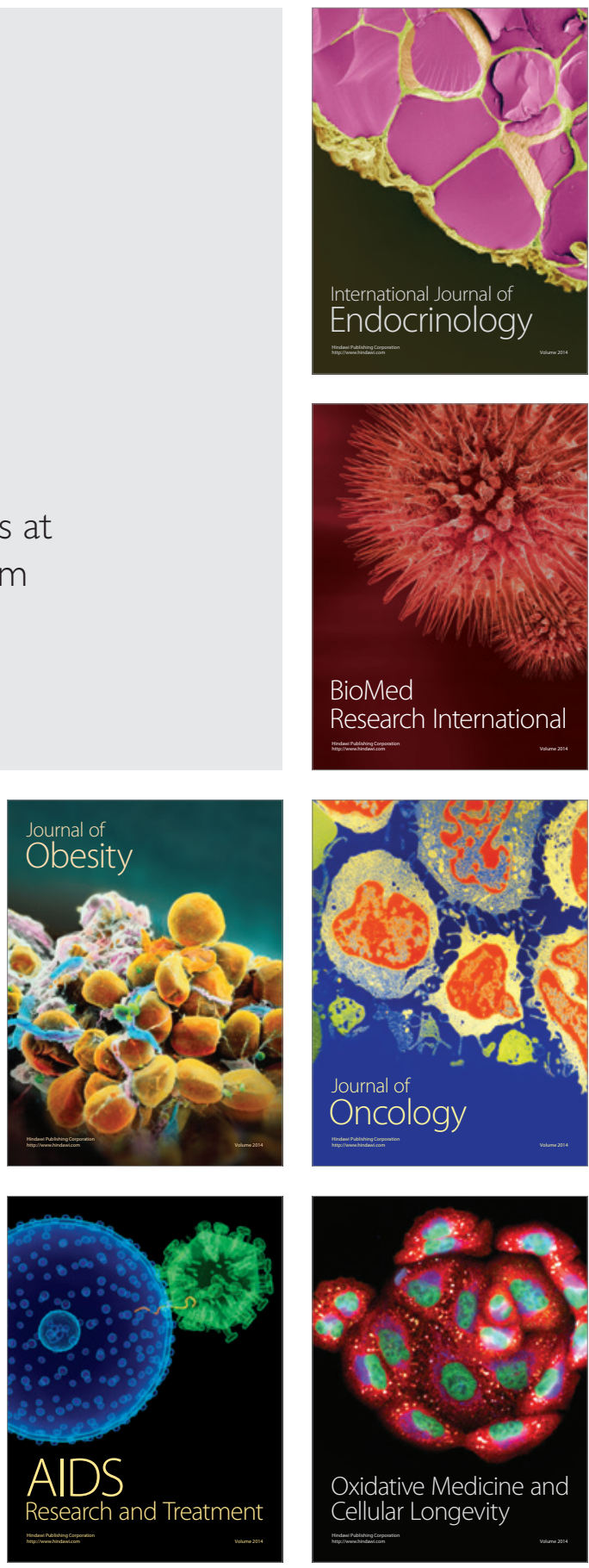